\title{
Ekologiczny nurt humanizmu w Centesimus annus
}

\section{Wprowadzenie}

Encyklika Centesimus annus zwraca uwagę na aspekty kryzysu ekologicznego, którego nie redukuje się tylko do kontekstu niszczenia przyrody i nadmiernego zużywania zasobów naturalnych. Niekiedy aspekt ochrony środowiska naturalnego odczytuje się w kluczu ekologizmu, uprawiającego specyficzny kult przyrody, w wyniku którego pomniejszany jest status człowieka. Przez uznanie biocentrycznej wartości przyrody ożywionej ekologizm staje się dziś nowym rodzajem ideologii politycznej ${ }^{1}$. Ten kierunek myślowy jest sprzeczny z tradycyjnym humanizmem podkreślającym wyjątkową wartość życia ludzkiego.

Opracowanie skupia się na ukazaniu ekologicznego nurtu humanizmu w Centesimus annus. Zajęcie się kategorią „ekologii” jest ważne ze względu na aktualność nauczania społecznego Kościoła, w którym - po blisko 25 latach od ogłoszenia Centesimus annus - papież Franciszek przedstawił w pierwszej encyklice ekologicznej Laudato si' koncepcję „ekologii integralnej”, kompleksowo łączącej problemy środowiska naturalnego ze sprawiedliwością społeczną.

$\mathrm{Na}$ początku opracowania wyjaśnia się termin „ekologia” i ukazuje się tzw. mentalność maltuzjańską, wyrażającą się w próbie regulacji wzrostu demograficznego za pomocą kontroli narodzin. Nawiązuje się także do występującej na forum onz wysokiej rangi działań na rzecz

1 C. Breuer, Die Ökologie des Menschen. Die Rede von Papst Benedikt Xvi. vor dem Bundestag, „Die neue Ordnung” 66 (2012), nr 2, s. 93-95; M. Ciszek, „Ekologizm” jako nowy nurt polityczny. Implikacje filozoficzno-etyczne, „Studia Ecologiae et Bioethicae” (2010), nr 2, s. 46. 
zachowania środowiska naturalnego wydającej się korelować z mniejszym zaangażowaniem na rzecz ochrony życia ludzkiego. Po ukazaniu zarysu kryzysu wartości moralnych opracowanie prezentuje dwie płaszczyzny ekologicznego nurtu humanizmu afirmującego osobę ludzką: „ekologię ludzką" i „ekologię społeczną".

Ekologiczny nurt humanizmu zaprezentowany w Centesimus annus wydaje się reakcją nauczania społecznego Kościoła na rozpowszechniony w nauce ekocentryczny paradygmat humanizmu ekologicznego ${ }^{2}$.

\section{Mentalność maltuzjańska a ekologia}

Termin „ekologia” wprowadził Ernst Haeckel w 1869 roku na oznaczenie dyscypliny naukowej zajmującej się badaniem związków zachodzących w przyrodzie między różnymi gatunkami roślin i zwierząt ${ }^{3}$. W drugiej połowie xx wieku znaczenie tego terminu uległo zmianie. Od lat 60. $\mathrm{xx}$ wieku termin ten zaczął być używany w odniesieniu do działań podejmowanych $\mathrm{w}$ związku z degradacją środowiska naturalnego w skali ogólnoświatowej ${ }^{4}$. Wyrazem tych działań było powstanie ruchów ekologicznych, które szczególnie pod koniec xx wieku - prezentując wartości postmaterialne - zaczęły dążyć do specyficznej zmiany kulturowej i moralnej5. Oznaką tych zmian są próby realizacji polityki międzynarodowej, która w kontekście eksplozji demograficznej z mniejszym naciskiem przedstawia programy zmierzające do sprawiedliwego podziału dóbr i postępu kulturowego, a bardziej wyraża się w działaniach na rzecz zachowania środowiska naturalnego i likwidacji ubóstwa, dopuszczając różne formy polityki antynatalistycznej ${ }^{6}$.

Szczególnie w latach 70. xx wieku tzw. mentalność maltuzjańska, wyrażająca się w próbie opanowania wzrostu demograficznego przez kontrolę przyrostu ludności za pomocą środków antykoncepcyjnych, sterylizacji i aborcji, była jednym z przejawów działań na rzecz ryzyka wyczerpania

2 Por. R. Czekalski, Paradygmat ekologiczny Henryka Skolimowskiego, Warszawa 2014.

3 W. Łużyński, Globalna kwestia społeczna. Wybrane zagadnienia z perspektywy nauczania społecznego Kościoła, Toruń 2013, s. 51.

4 T. Ślipko, Ekologia, w: Słownik społeczny, red. B. Szlachta, Kraków 2004, s. 165.

5 P. Matczak, Problemy ekologiczne jako problemy społeczne, Poznań 20oo, s. 63.

6 EV 16. 
się zasobów naturalnych dla szybko wzrastającej ludności świata ${ }^{7}$. Od lat 70. Xx wieku na forum onz toczy się dyskusja nad włączeniem tzw. „prawa do aborcji” w zakres pojęciowy „praw reprodukcyjnych”, które próbowano przeforsować podczas konferencji onz dotyczącej ludności i rozwoju w Kairze w 1994 roku. W obecnej sytuacji dyskusja o tych prawach powraca i pojawia się choćby w kontekście ustanawiania celów zrównoważonego rozwoju na lata $2015-2030^{8}$.

\section{Ogólnoświatowy program zrównoważonego rozwoju}

$\mathrm{Z}$ perspektywy 25-lecia Centesimus annus uwzględnienie aspektów ekologicznych w tym dokumencie można wiązać z przyjęciem ogólnoświatowego programu rozwoju społeczno-gospodarczego w 1992 roku, kiedy podczas Szczytu Ziemi w Rio de Janeiro konferencja onz „Środowisko i rozwój” umocowała międzynarodowy program rozwoju: Agendę 21, na fundamencie antropocentrycznym, stwierdzając, że „,istoty ludzkie są $\mathrm{w}$ centrum zainteresowania $\mathrm{w}$ procesie zrównoważonego rozwoju” i mają "prawo do zdrowego i twórczego życia w harmonii z przyrodą".

Antropocentryczna interpretacja Agendy 21 różni się od współczesnych ekocentrycznych koncepcji etycznych, które stoją w opozycji do fundamentalnych zasad etyczno-społecznych katolickiej nauki społecznej zakorzenionych $\mathrm{w}$ personalizmie ${ }^{10}$. W kontekście ogólnoświatowego konceptu rozwoju trzeba ukazywać syntezę wszystkich praw człowieka, unikając wyakcentowywania tylko niektórych z nich, np. prawa do życia w czystym środowisku naturalnym ${ }^{11}$. Przy takim ujęciu słabną interpretacje biocentryczne, fizjocentryczne i patocentryczne, które nadają zwierzętom czy przyrodzie nieożywionej większe prawa niż człowie-

7 S. Fel, Maltuzjanizm, w: Encyklopedia katolicka (KUL), t. 11, Lublin 2006, s. 995.

${ }^{8}$ Organizacja Narodów Zjednoczonych, The future we want. Sustainable development goals 2015-2030, $\mathrm{nr}$ 145-146, http://www.uncsd2012.org/content/documents/727The\%20 Future\%20We\%2oWant\%2019\%20June\%201230pm.pdf (26.01.2016).

9 Konferencja Narodów Zjednoczonych „Środowisko i rozwój“, Zasady ogólnych praw i obowiązków, Rio de Janeiro 1992, zasada 1.

${ }^{10}$ Por. R. Marx, H. Wulsdorf, Christliche Sozialethik. Konturen - Prinzipien - Handlungsfelder, Padeborn 2002, s. 334-339.

${ }^{11}$ F. J. Mazurek, Godność osoby ludzkiej podstawa praw człowieka, Lublin 2001, s. 409. 
kowi ${ }^{12}$. W ten sposób zarys ogólnoświatowego rozwoju, przedstawiony $\mathrm{w}$ antropocentrycznej interpretacji zrównoważonego rozwoju, powinien bardziej ukierunkowywać się ku prymatowi osoby ludzkiej i wszystkich przysługujących jej praw. Zachowaniu podstawowej wartości, jaką jest osoba ludzka, służy nowa zasada etyczno-społeczna katolickiej nauki społecznej - zasada zrównoważonego rozwoju ${ }^{13}$.

\section{Kryzys wartości moralnych}

Centesimus annus wskazuje na przyrodnicze uwarunkowania stylu życia ludzkiego i zaznacza, że u podłoża kwestii ekologicznej leży błędna koncepcja człowieka. Jan Paweł II zauważa w społeczeństwie dobrobytu niebezpieczeństwo wyobcowania i konsumizmu, które wprowadzają człowieka w sieć błędnego i powierzchownego zaspokajania potrzeb $^{14}$. Ujawnia się ono w bezkrytycznym stosowaniu w praktyce zdobyczy naukowych i technologicznych, a także w nieodpowiedzialnych nawykach konsumpcyjnych. W ostateczności taka prawidłowość absolutyzuje konsumpcyjne style życia, zwiększa produkcję, zużycie energii i czyni eksploatację ograniczonych zasobów naturalnych nieodpowiedzialnym działaniem ${ }^{15}$. Skutkiem tego pojawia się niebezpieczeństwo absolutyzacji gospodarki, która powinna być tylko jednym $\mathrm{z}$ wymiarów złożonej działalności ludzkiej ${ }^{16}$. W ten sposób dochodzi do zachwiania hierarchii wartości - człowiek bardziej ceni w swoim życiu wartości materialne „mieć” niż wartości „byćc ${ }^{17}$. Wyrazem tego niezrównoważenia wydaje się także większa troska o dobrobyt i dostęp do zasobów naturalnych niż o człowieka znajdującego się w trudnych warunkach życiowych ${ }^{18}$.

${ }^{12}$ Por. S. Fel, Katolicka nauka społeczna $w$ twórczości naukowej Janusza Mariańskiego, „Roczniki Nauk Społecznych” (2015), nr 2, s. 190-194.

${ }^{13}$ Por. M. Vogt, Prinzip Nachhaltigkeit. Ein Entwurf aus theologisch-ethischer Perspektive, München 2009.

${ }^{14}$ CA 41.

${ }^{15}$ Por. J. Mariański, Kościół a współczesne problemy społeczno-gospodarcze. Kwestie wybrane, Lublin 1992, s. 148-151.

${ }^{16}$ CA 39.

${ }^{17}$ SRS 28 .

${ }_{18}$ Rozdroża ekologii, red. T. Ślipko, A. Zwoliński, Kraków 1999, s. 33. 
Centesimus annus stanowi wołanie o poszanowanie godności osoby ludzkiej w działaniu politycznym odnoszącym się do obszaru społeczno-gospodarczego. Pierwszeństwo osoby ludzkiej i personalizm, który przenika tę encyklikę, sam w sobie domaga się, by zauważyć w niej personalistyczną zasadę społeczną ${ }^{19}$. Jest ona szczególnie ważna w związku z kryzysem moralnym i potrzebą kształtowania kultury humanistycznej.

\section{Płaszczyzny ekologicznego nurtu humanizmu}

Problematyka ekologiczna nie należy do głównych wątków nauczania społecznego Kościoła katolickiego, jednak Kościół - w służbie wartościom humanistycznym - widzi potrzebę wypowiadania się także na tematy ekologiczne, ponieważ człowiek - $z$ natury będąc istotą wolną i rozumną, podmiotem praw i obowiązków - jest zależny od jakości środowiska naturalnego ${ }^{20}$. Jan Paweł II w Centesimus annus dobitnie podkreślił humanistyczny kierunek ochrony środowiska naturalnego.

Humanizm w ujęciu Władysława Piwowarskiego jest całością „kierunków myślowych i praktycznych postaw koncentrujących się wokół samego człowieka, sensu i celu jego życia, szacunku dla jego godności, troski o jego wolność, szczęście i swobodny rozwój”"21. Niepodważalną wartością humanizmu jest osoba ludzka, którą traktuje się jako cel sam w sobie. Dla uwypuklenia treści naturalnego i społecznego środowiska życia ludzkiego potrzebne jest także ekologiczne objaśnienie humanizmu. Należy zaznaczyć, że ukazanie środowiska naturalnego jako niezbędnego obszaru życia ludzkiego nie odbiera osobie ludzkiej należnego jej prymatu ze względu na wrodzoną godność. Humanizm ekologiczny strzeże niepodważalnej wartości każdej osoby ludzkiej. Opowiada się za nienaruszalnym charakterem przysługującego jej prawa do życia i korelującego z nim obowiązku do jego godnego utrzymania.

Ekologiczny nurt humanizmu w Centesimus annus wniósł w interpretację aspektów ekologicznych ważną treść personalistyczną i przypomniał,

19 J. Mazur, Persona in societate. Wybrane zagadnienia chrześcijańskiej nauki o człowieku, Kraków 2014, s. 72.

${ }^{20}$ J. Mariański, Problem ochrony środowiska i „ekologii ludzkiej”, w: „Centesimus annus”. Tekst $i$ komentarze, red. F. Kampka, C. Ritter, Lublin 1996, s. 328.

${ }^{21}$ W. Piwowarski, Humanizm, w: Słownik katolickiej nauki społecznej, red. W. Piwowarski, Warszawa 1993, s. 64. 
że człowiek jako osoba ludzka jest ponadczasową i pierwszorzędną wartością ${ }^{22}$. Kościół w nauczaniu społecznym konsekwentnie wyraża prawdę, że to nie żadne inne stworzenie, a tylko człowiek został stworzony na obraz i podobieństwo Boże i „wszystkie rzeczy które są na ziemi, należy skierować ku człowiekowi, stanowiącemu ich ośrodek i szczyt" ${ }^{\prime 23}$. Człowiek jako osoba ludzka w tej konsekwencji posiada niepodważalne prawo do życia.

Afirmacja osoby ludzkiej w ekologicznym nurcie humanizmu została ukazana w pojęciach: „ekologia ludzka” i „ekologia społeczna”.

\section{5. „Ekologia ludzka”}

W nauczaniu społecznym Kościoła „ekologia ludzka” po raz pierwszy została wyrażona w Centesimus annus w słowach: „oprócz irracjonalnego niszczenia środowiska naturalnego należy [...] przypomnieć bardziej jeszcze niebezpieczne niszczenie środowiska ludzkiego, czemu zresztą bynajmniej nie poświęca się koniecznej uwagi. [...] Zbyt mało wagi przywiązuje się do ochrony warunków moralnych prawdziwej «ekologii ludzkiej». Człowiek [...] musi respektować naturalną i moralną strukturę, w jaką został wyposażony"24.

Koncepcja „ekologii ludzkiej” oznacza „harmonijne zespolenie teorii przyrodniczych i społecznych z zagadnieniami humanistyki i kultury"25. „Ekologia ludzka” jest centralną dla chrześcijaństwa tezą o roli Boga Stwórcy kierującego procesami ewolucji świata, ujmuje życie ludzkie i zdrowie jako najwyższe wartości, które jednak nie mają charakteru absolutnego. W „ekologii ludzkiej” godność osoby ludzkiej pozostaje naczelną normą, a ochrona środowiska naturalnego ściśle powinna współgrać z zachowaniem prawa do życia ${ }^{26}$. „Jeśli nie uznaje się w samej rzeczywistości znaczenia człowieka ubogiego, ludzkiego embrionu, osoby niepełnosprawnej [...] trudno będzie usłyszeć wołanie samej przyrody.

${ }^{22}$ M. Vogt, Umweltschutz, Naturschutz, Tierschutz, w: Handbuch der Katholischen Soziallehre, Hg. A. Rauscher, Berlin 2008, s. 430.

${ }^{23}$ KDK 12.

${ }^{24}$ CA 38 ; por. LS $5,115$.

${ }_{25}$ S. Jaromi, Koncepcja ekologii ludzkiej według Jana Pawła II, „Kwartalnik Naukowy Fides et Ratio" 9 (2012), nr 2, s. 10.

${ }^{26}$ Por. tamże. 
[...] Jeśli człowiek ogłasza siebie jako niezależnego od rzeczywistości i staje się władcą absolutnym, kruszy się sama podstawa jego istnienia, ponieważ zamiast pełnić rolę współpracownika Boga w dziele stworzenia, człowiek zajmuje Jego miejsce i w końcu prowokuje bunt natury" ${ }^{27}$. Gdy chroni się godność osoby ludzkiej, wówczas równocześnie ochrania się środowisko naturalne, które jest częścią środowiska ludzkiego. Według papieża środowisko naturalne ulega większej degradacji, gdy człowiek sam zatraca troskę o swoją godnośćc 28 .

Dla Jana Pawła II kryzys ekologiczny w głównej mierze jest problemem moralnym, który ogniskuje się na braku szacunku dla życia. Niepokojącym faktem stają się działania, gdy człowiek bardziej skłania się ku zabezpieczeniu środowiska naturalnego niż zadbaniu o odpowiednie warunki swojego integralnego rozwoju ${ }^{29}$. W takim sensie w rozwijanej dziś koncepcji zrównoważonego rozwoju, w której bardziej skupiono się na akcentowaniu aspektów ochrony środowiska naturalnego ${ }^{30}$, nie można zapomnieć o wymiarze społeczno-gospodarczym.

\section{6. „Ekologia społeczna”}

Paralelnie do pojęcia „ekologii ludzkiej” Centesimus annus wprowadza pojęcie „ekologii społecznej”. Odnosi się ono do problemów związanych z rozwojem obszarów miejskich, w których wyraża się konieczność zastosowania urbanistyki troszczącej się o życie godne osoby, jak również do odpowiedniego uwarunkowania pracy ${ }^{31}$. Pilna staje się potrzeba humanizmu integrującego różne dziedziny wiedzy, w tym obszar gospodarki zakorzenionej w społeczeństwie. Niezbędnym działaniem jest umacnianie podmiotowości społeczeństwa poprzez budowanie etosu solidarności wyrażającej się w silnych więziach społecznych ${ }^{32}$. W „ekologii społecznej”

${ }^{27}$ CA 37; LS 117

${ }_{28}$ B. Sutor, Etyka polityczna. Ujęcie całościowe na gruncie chrześcijańskiej nauki społecznej, Warszawa 1994, s. 362 n.

29 R. Czekalski, Godność osoby ludzkiej (Nauczanie Jana Pawła II), Warszawa 2007, s. 71, 152.

${ }^{30}$ B. Baerlocher, Natur und soziales Handeln. Ein sozialtheoretisches Konzept für die Nachhaltigkeitsforschung, Frankfurt-New York 2013, s. 11-12.

${ }^{31}$ CA 38.

${ }^{32}$ A. Dylus, Reforma państwa społecznego. Przebudowa strukturalna i przemiana mentalno-moralna, w: „Centesimus annus”. Tekst i komentarze, s. 186-19o. 
analiza problemów środowiskowych ściśle łączy się z analizą jakości życia człowieka, jego rodziny, środowiska pracy, kontekstu urbanistycznego oraz relacji każdej osoby z samą sobą ${ }^{33}$.

\section{Zakończenie}

Od momentu ogłoszenia Centesimus annus w nauczaniu społecznym Kościoła znacznie dobitniej ukazuje się problemy „ekologii ludzkiej”, a „kwestię ekologiczną rozszerza się na różne problemy społeczne” ${ }^{34}$. Zdaniem Janusza Mariańskiego konieczne jest poszerzenie horyzontów ekologii poprzez łączne przemyślenie problemów środowiska naturalnego i sprawiedliwości społecznej ${ }^{35}$. Centesimus annus wskazuje na nowe horyzonty ekologiczne, w których widoczna władza człowieka nad przyrodą musi uwzględniać postęp moralny, a przede wszystkich ochronę życia ludzkiego. Ekologiczny nurt humanizmu w Centesimus annus odnosi się więc głównie do „ekologii ludzkiej”, która oznacza niezbędną relację życia człowieka $\mathrm{z}$ prawem moralnym wpisanym w naturę ludzką ${ }^{36}$. Jest to fundament „ekologii integralnej”, służącej tworzeniu bardziej godnych warunków życia ludzkiego i trwałości społeczeństw ${ }^{37}$.

\section{Bibliografia}

Baerlocher B., Natur und soziales Handeln. Ein sozialtheoretisches Konzept für die Nachhaltigkeitsforschung, Campus Verlag, Frankfurt-New York 2013.

Breuer C., Die Ökologie des Menschen. Die Rede von Papst Benedikt XVI. vor dem Bundestag, „Die neue Ordnung” 66 (2012), s. 84-102.

Ciszek M., „Ekologizm” jako nowy nurt polityczny. Implikacje filozoficzno-etyczne, „Studia Ecologiae et Bioethicae” (2010), nr 2, s. 45-51.

33 LS $141,157$.

${ }^{34}$ J. Mariański, Troska Kościoła o ochronę środowiska naturalnego, w: Katolicka nauka społeczna. Podstawowe zagadnienia z życia gospodarczego, red. J. Kupny, S. Fel, Katowice 2003, s. 213.

${ }^{35}$ J. Mariański, Problem ochrony środowiska i „ekologii ludzkiej”, w: „Centesimus annus”. Tekst i komentarze, s. 338.

${ }^{36} \mathrm{EV} 7 \mathrm{O}$.

37 LS 155. 
Czekalski R., Godność osoby ludzkiej (Nauczanie Jana Pawła II), BEL Studio, Warszawa 2007.

Czekalski R., Paradygmat ekologiczny Henryka Skolimowskiego, Warszawskie Towarzystwo Teologiczne, Warszawa 2014.

Dylus A., Reforma państwa społecznego. Przebudowa strukturalna i przemiana mentalno-moralna, w: „Centesimus annus”. Tekst i komentarze, red. F. Kampka, C. Ritter, Redakcja Wydawnictw KUL, Lublin 1998, s. 173-191.

Fel S., Katolicka nauka społeczna w twórczości naukowej Janusza Mariańskiego, „Roczniki Nauk Społecznych” (2015), nr 2, s. 181-200.

Fel S., Maltuzjanizm, w: Encyklopedia katolicka (KUL), t. 11, Lublin 2006, s. 994996.

Franciszek, Encyklika Laudato si', Libreria Editrice Vaticana, Watykan 2015.

Jan Paweł II, Encyklika Centesimus annus, przedruk: Libreria Editrice Vaticana, Włocławek 1991.

Jan Paweł II, Encyklika Evangelium vitae, Libreria Editrice Vaticana, Watykan 1995.

Jan Paweł II, Encyklika Sollicitudo rei socialis, Ośrodek Chrześcijańskiej Myśli Społecznej „Augustinum”, Warszawa 1988.

Jaromi S., Koncepcja ekologii ludzkiej według Jana Pawła II, „Kwartalnik Naukowy Fides et Ratio" 9 (2012), nr 2, s. 5-12.

Konferencja Narodów Zjednoczonych „Środowisko i rozwój”, Zasady ogólnych praw i obowiązków, Rio de Janeiro 1992.

Łużyński W., Globalna kwestia społeczna. Wybrane zagadnienia z perspektywy nauczania społecznego Kościoła, Wydawnictwo Naukowe Uniwersytetu Mikołaja Kopernika, Toruń 2013.

Mariański J., Kościół a współczesne problemy społeczno-gospodarcze. Kwestie wybrane, Towarzystwo Naukowe KuL, Lublin 1992.

Mariański J., Problem ochrony środowiska i „ekologii ludzkiej”, w: „Centesimus annus”. Tekst $i$ komentarze, red. F. Kampka, C. Ritter, Redakcja Wydawnictw KUL, Lublin 1996, s. 325-339.

Mariański J., Troska Kościoła o ochrone środowiska naturalnego, w: Katolicka nauka społeczna. Podstawowe zagadnienia z życia gospodarczego, red. J. Kupny, S. Fel, Księgarnia św. Jacka, Katowice 2003, s. 202-219.

Marx R., Wulsdorf H., Christliche Sozialethik. Konturen - Prinzipien - Handlungsfelder, Bonifatius, Padeborn 2002.

Matczak P., Problemy ekologiczne jako problemy społeczne, Wydawnictwo Naukowe UAM, Poznań 2000. 
Mazur J., Persona in societate. Wybrane zagadnienia chrześcijańskiej nauki o człowieku, Wydawnictwo Naukowe Uniwersytetu Papieskiego Jana Pawła II, Kraków 2014.

Mazurek F. J., Godność osoby ludzkiej podstawa praw człowieka, Redakcja Wydawnictw KUL, Lublin 2001.

Organizacja Narodów Zjednoczonych, The future we want. Sustainable development goals 2015-2030, http://www.uncsd2012.org/content/documents/727The\%2oFuture\%2oWe\%2oWant\%2019\%20June\%201230pm.pdf (26.01.2016).

Piwowarski W., Humanizm, w: Słownik katolickiej nauki społecznej, red. W. Piwowarski, Instytut Wydawniczy PAX - Wydawnictwo Misjonarzy Klaretynów PALABRA, Warszawa 1993, s. 64-65.

Rozdroża ekologii, red. T. Ślipko, A. Zwoliński, Wydawnictwo wAM, Kraków 1999. Ślipko T., Ekologia, w: Stownik społeczny, red. B. Szlachta, Wydawnictwo WAM, Kraków 2004, s. 165-175.

Sobór Watykański II, Konstytucja Gaudium et spes, w: Sobór Watykański II. Konstytucje. Dekrety. Deklaracje, Pallottinum, Poznań 2002, s. 526-606.

Sutor B., Etyka polityczna. Ujęcie całościowe na gruncie chrześcijańskiej nauki społecznej, Warszawa 1994.

Vogt M., Prinzip Nachhaltigkeit. Ein Entwurf aus theologisch-ethischer Perspektive, Oekom Verlag, München 2009.

Vogt M., Umweltschutz, Naturschutz, Tierschutz, w: Handbuch der Katholischen Soziallehre, Hg. A. Rauscher, Duncker \& Humbolt, Berlin 2008, s. 419-432.

\begin{abstract}
Abstrakt
Opracowanie jest próbą ukazania nurtu humanizmu o charakterze ekologicznym $\mathrm{w}$ encyklice Centesimus annus. Wieloznacznie rozumiany humanizm definiuje się za Władysławem Piwowarskim, który wskazywał na potrzebę uwypuklenia w tym kierunku myślowym niektórych treści. W ten sposób w nauce społecznej Kościoła wyłania się nurt humanizmu podkreślający płaszczyzny ekologii afirmujące osobę ludzką: ekologię ludzką i ekologię społeczną. W 25-lecie Centesimus annus ekologiczny nurt humanizmu wydaje się nawiązywać do coraz bardziej widocznych nowych wymiarów kwestii społecznych charakteryzujących się wysoką rangą działań na rzecz zachowania środowiska naturalnego, korelujących z mniejszym zaangażowaniem na rzecz ochrony życia ludzkiego. Wraz z tym zjawiskiem od połowy xx wieku dostrzega się dobitniej tzw. mentalność
\end{abstract}


maltuzjańską, wyrażającą się w próbie regulacji wzrostu demograficznego za pomocą kontroli przyrostu ludności. Te zjawiska ukazują nowe oblicza współczesnej kwestii społecznej, wobec których katolicka nauka społeczna nie może pozostać obojętna.

\title{
Ecological trend of humanism in Centesimus annus
}

\begin{abstract}
The paper is an attempt to show the ecological humanism trend in the Centesimus annus encyclical. The ambiguously understood humanism is defined by Władysław Piwowarski who pointed to the need to highlight some of the content in this direction of thought. This way, in the Church's social doctrine emerges the trend of humanism that emphasizes planes of ecology affirming the human person: human ecology and social ecology. On the 25th anniversary of Centesimus annus the ecological humanism trend seems to make reference to more visible dimensions of social issues that are characterized by a high rank of activities for the preservation of the environment, correlating with less commitment to the protection of human life. Along with this phenomenon, the Malthusian mentality, expressed in the attempt to regulate demographic growth by controlling population growth, has seemed more distinct since the first half of the 2oth century. These phenomena demonstrate new faces of the contemporary social issue to which the Catholic social teaching cannot be indifferent.
\end{abstract}

